\title{
Development of an House Hold Biogas Digester
}

\author{
Ejiko S. O..$^{*}$, Adewuyi R. A. ${ }^{2}$, Filani O. A. ${ }^{3}$ \\ ${ }^{1,2}$ Mechanical Engineering Department, the Federal Polytechnic, Ado-Ekiti \\ ${ }^{3}$ Agricultural and Bio-Environmental Engineering Department, Federal Polytechnic, Ado-Ekiti
}

*Corresponding Author: Ejiko S. O., Mechanical Engineering Department, the Federal Polytechnic, Ado-Ekiti

\begin{abstract}
Biogas production has contributed greatly as an alternative source of fuel power supply in developing nation reducing the concentration on petroleum product. The production and utilization of biogas plays a significant role in disposing and converting municipal and agricultural waste into fuel that can be use at home for cooking and lighting. Biogas digester for household application that is affordable and easy to maintain was developed using mild steel material. The developed digester is of cylindrical type with a height of $1.22 \mathrm{~m}$ and diameter of $0.56 \mathrm{~m}$. The volume of $0.07 \mathrm{~m}^{3}$ was designed to accommodate the produced biogas. Experimentation process shows that the generation of biogas increases between the temperature range of $30^{\circ} \mathrm{C}$ to $40^{\circ} \mathrm{C}$. The developed metallic bio digester was found to be suitable and efficient in the production of biogas from biodegradable waste at the mesophilic temperature of $38.8^{\circ} \mathrm{C}$.
\end{abstract}

Keywords: Anaerobic, Biogas, Digester, Fuel, Methane

\section{INTRODUCTION}

Biogas is a gas generated from the anaerobic digestion of organic waste in which methane gas is produced and can be use to provide light or heat needed for various application. Methane is the principal content of the gas produce when organic material such as manure decomposed in than airless environment producing a useful flame without smoke and explosion and then used for various application. Furthermore, this is achieved with the designed and construction of biogas plant, the biogas plant is an anaerobic digester of organic material for the purpose of heating waste and consequently, the biogas fuel is generated the biogas is an alternatives to other gases used as fuel ,its advantage over other source of fuel cannot be overemphasized (Fulford, et. al., 1988). The biogas apart from being used as cooking fuel serves other purpose which includes generation of electricity and manure for agricultural uses such as fertilizer (Polprasert, 1992).

The biogas is produced using varieties of raw material such as plant material, food waste and animal dung in a reactor. Successful construction of the biogas plant is done in consideration of the setting up and maintenance cost, the government policy and gas handling process, the type of material needed for the construction, the site location for the plant (Amon et. al., 2003). Kerosene and other energy sources produce several gases which are dangerous such as carbon monoxide which is poisonous. Nitrogen dioxide is a throat and lung irritant, and sulphur dioxide can cause difficulty in breathing; this occurs when fumes from a heater are not removed by a chimney, the gases are released into the room (Mukumba et. al., 2015). This could be solved by the use of biogas technology.

\section{LITERATURE REVIEW}

The use of petrol, kerosene firewood and other sources of energy have been found to be not only bad for the environment but it has detrimental health effects. Health problems due to smoke inhalation cause 1.6 million deaths per year, $28 \%$ of deaths due to indoor air pollution occur in many countries like Nigeria, these effects also account for $20 \%$ of fatalities in children fewer than 5 years of age. To alleviate or end some of these unsustainable and dangerous practices, the installation of a biogas settler with a latrine feed has been proposed. The system will collect waste from human and animal waste and convert it to energy and fertilizer. 
Ever since the beginning of mankind man has depended so much on the use of heat, energy this form of energy is widely used in various area and ramification of mankind, this include industrial application, environmental, household application amongst others.

Basically this project treats the need for the generation of heat energy for household, the use of heat energy in the household cannot be overemphasized, and mankind in the quest for useful energy has been applying so many method in generating the needed energy for the household consumption, for instance, the burning of wood, which often generate heat and emit a lot of carbon which often result to various health hazard.

However this was improved by the inception of technology in which natural gas gotten out from the fractional distillation of crude oil and the use of electricity generated energy in the household. In a simpler context, this method has been considered and seen be of many disadvantages, which includes: high capital cost for setting up (e.g. the natural cost), bad odor generation, emission of various chemical compound, which are harmful to the user (E.g. wood burning), high cost of maintenance (E.g. natural gas) and high skill in handling (electric heater and natural gas).

Therefore this led to the generation of the bio-gas (i.e. gas generated from living organism) using the remains and waste in the house in which the needed energy is generated. But it is also a health risk. The spread of disease is increased during the raining season when these deposits are washed into water sources that in turn become contaminated (Raven, 2011).

\subsection{Limitation of Biogas}

- The process is not very attractive economically (as compared to other bio fuels) on a large industrial scale.

- It is very difficult to enhance the efficiency of biogas systems.

- Biogas contains some gases as impurities, which are corrosive to the metal parts of internal combustion engines.

- Not feasible to locate at all the location.

\subsection{Solution Provided by the Biogas}

\section{$>$ Environmental Impacts}

Reduction of the biomass resource depletion: biogas plants can help tackle deforestation, especially in a context where households mainly use firewood or charcoal for cooking and heating. Indeed, an extensive use of firewood or charcoal may result in an unsustainable situation where the wood demand exceeds the sustainable wood production (Polprasert, 1992).

\section{$>$ Reduction of Greenhouse Gases (GHG) Emissions}

The use of sustainable wood for heating or cooking results in positive GHG emissions, whereas the use of biogas is generally neutral with regards to GHG emissions (provided that organic materials use to feed the bio- digester are renewable and that there is no methane leakage from plant). As a consequence, in a country where wood production is non-sustainable, biogas plant can displace the use of firewood or charcoal, resulting in a reduction of GHG emissions (polprasert, 1992).

\section{Social Impacts Quality of Life}

Biogas plant help improves beneficiaries' quality of life. First, they reduce the workload usually required for typical task such as firewood collection and fie tending. In addition, cooking with firewood or charcoal usually results in the production of soot which usually soils the kitchen utensil.

Gender quality: improved gender quality is a direct consequence of the previous point, since women are predominantly involved in the housework. Thanks to the reduction of their workload, women can spend more time on other activities and on education, hence a reduction on gender disparities.

Health and sanitation: Indoor smoke pollution related to the use of firewood or charcoal may induce health risks such as respiratory diseases (no particulate matter emission unlike firewood or charcoal). In addition, bio-digesters reduce the pathogen content of organic materials. The sanitary condition of the household can consequently be enhanced thanks to domestic biogas units. 
Education: the installation of biogas lamp can enable children to study later in the evening. Indeed, the lighting quality of biogas lamps is generally better than traditional lighting methods (e.g. kerosene lamps). Children that have access to a proper lighting can study up to 2 hours more per evening than children with poor lighting conditions (Meynell, (2013)

Food security: the use of bio-slurry as a fertilizer improves crop yields compared to traditional manure. It consequently contributes to food security for beneficiaries and the community in general.

\section{$>$ Economic Impacts}

Economic impacts for beneficiaries; by displacing the use of firewood or charcoal, biogas can help to reduce household energy expenses. In addition, the increase of crop yield related to the use of bio slurry as a fertilizer can result in higher income for farmers. Properly used, bio-slurry can improve crop yield by $10 \%$ to $50 \%$ or more, compared to traditional fertilizers (e.g. compost). Economic impacts for the community; the diffusion of biogas plants stimulates the national economy. Indeed, a large dissemination of biogas units results in job creation in the construction sector, or for specific training of masons or plumbers (chukwuma, et.al., (2014).

\section{Renewable Source of Energy}

Biogas is considered to be renewable sources of energy. Since it often produced from the materials that form sewage and waste products, the only time it will be depleted is when we stop producing any waste.

\section{$>$ Non-Polluting}

It is also considered to be non-polluting in nature. The production of biogas does not require oxygen, which means that resources are conserved by not using any further fuel.

\section{$>$ Cheaper Technology}

Application for biogas is increasing as the technology to utilize it gets better. It can be used to produce electricity and for the purpose of heating as well. Compressed Natural Gas (CNG) is biogas that has been compressed and can be used as a fuel for vehicles. Production can be carried out through many small plants or one large plant.

\section{$>$ Large Number of Jobs}

Either ways, work opportunities are created for thousands of people in these plants. These jobs are a blessing in rural areas, which are the targeted grounds for the use of biogas. In fact, biogas can easily be decentralized, making it easier to access by those living in remote areas or facing frequent power outages.

\section{$>$ Little Capital Investment}

Biogas is easy to set up and requires capital investment on a small scale basis. In fact, many farms can become self sufficient by utilizing biogas plants and the waste material produced by their livestock each day. A single cow can provide enough waste materials within a day to power a light bulb the entire day.

\section{$>$ Reduces Greenhouse Effect}

It also reduces the green house effect by utilizing the gases being produced in landfills as forms of energy. This is a major reason why the use of biogas has started catching on. It recycles most forms of biodegradable waste and works on simple forms of technology.

\section{Environment Benefits on a Global Scale}

Biogas plants significantly lower the greenhouse effects on the earth's atmosphere. The plant lower methane emissions by entrapping the harmful as and using it as fuel.

\section{FaCtor that Influence the Design of a Biogas Plant}

\subsection{Position}

To fit a biogas plant into manure handling system, the position thereof must be critically determined. A decision must be made whether the plant will function as part of the exiting manure handling system or if additional changes are necessary for the system to function. 


\subsection{Safety}

A digester may be close to animal housing, but the gas container and equipment that handle the gas must be erected separately for safety purpose s. ensure that enough natural ventilation exists around the digester and gas container. Unnecessary screens or roofs around the digester and gas container must be prevented, since the gas can collect and lead to explosion.

\subsection{Availability of Animal Waste}

Animal waste should be available daily because the digester has to be fed with a certain amount of fresh manure every day. This also implies that the same amount of digested manure as effluent will be produced, due to the applying of fresh manure.

\subsection{Amount of the Biogas Required for Various Applications}

Biogas is generally used for cooking, lighting and heating of water. At the larger plants it is also used as fuel for standalone internal combustion engines. Where a specific need for the application of biogas arises, the digester should be designed to produce the volume of biogas required per day.

Possible applications of biogas may include the following:

$>$ Cooking purpose;

The amount of biogas required for coking purposes per person per day will be determined by:

- The method used for the preparation of food, e.g. baking, frying or cooking.

- The type of food being prepared.

- How economically the biogas is being used, e.g. is the gas turned down when the water in the pot reaches boiling point.

$>$ Lighting; Biogas can be utilized where electricity is not available.

Heating; Biogas can be utilized where electricity is not available.

\section{FACTORS CONSIDERED IN THE GENERATION OF BIOGAS}

The following factor is considered in the biogas generation process are the temperature and $\mathrm{PH}$, materials, retention time and blending

\subsection{Temperature and $\mathbf{P H}$}

Two of the most importance factor for prosper anaerobic digestion and methane production and $\mathrm{PH}$. Failure to regulate these two factor is among the most common problem with a digester .Most anaerobic bacteria perform best in warmer atmosphere .This is why micro-digest $\mathrm{s}$ are most common in area closer to the equator . this does not mean a micro digester will not function in more northerly climate, but it does affect design decision, as the digester may need to be insulated or even heated to make large amount of methane anaerobic digestion does not stop completely at lower temperature but methanogenesis is the stage most seriously hindered by low temperature and this will reduce methane production there is evidence, however that plant base feedstock may perform better at low temperature than do manure-base system.(Rutz,1996).

Along with $\mathrm{PH}$ is vital to digester heath. The $\mathrm{PH}$ is a measure of the acidity or alkalinity of the content of the digester .just as in the human digestive system, too much acid creates indigestion in the anaerobic system. Pure water is said to be a natural, with a PH level of about 7. Acid have PH number below 7, while base have number above 7.a digester operate best near the neutral point, up to a $\mathrm{PH}$ up to 8.5. In the early stage of the anaerobic process, when the digester is making acid, the PH can drop to 6or below .when it reaches methanogenensis, it will operate in the 7.5 to 8.5 range (Lofler, 2000).

\subsection{Materials}

Almost all organic material can be used as feeding materials for anaerobic digestion, if it complies with the nutrition requirement of the bacterial bacterial need nitrogen, phosphorus, trace element and hydrocarbon it is important that the feeding materials must be free of solid such as sand, stones or plant materials with an excessive fiber and toxic ingredients. 


\subsection{Retention Time}

This is the that the waste is allowed to digest in the digester if the above requirement can be optimize, the digestion time (retention time) can be between 15 and 35 days for a heater digester .A retention time of 15 to 25 days is usually prefer, since it reduce the digester size and handle shock loading in it can be said that digestion is reach when the volatile solid have reduced by between $30 \%$ and $60 \%$ of the original raw sludge.

\subsection{Factors That Influence the Retention Time}

- Temperature in the digester $\left(35^{0} \mathrm{C}\right.$ or ambient temperature $)$

- The effective volume of the digester

- Measure of blending

- Volatile solid loading(\% VS)

\subsection{Blending}

By mixing the contents of the digester, intimidate contact between the bacterial and raw sludge is obtained, whereby the release of biogas is promoted and the foaming of a thick layer of foam on the top is prevented. The blending must be done in such a way that no deposit of heavier material occur on the bottom

\section{MeThodology}

In order to achieve the specification of the developed biogas plant for a region an assessment of the number of people per household was carried out to establish the raw material requirement for the plant sustainability. Preliminary survey to identify the availability of the water and location of materials for construction and to assess the condition of the proposed site were also carried out the number of occupant per household was found to be seven and they showed willingness to use biogas the analysis and design was based on the information obtained. The average number of cow per household was found to be 10 and the quantity of the dump per cow was experimentally estimated to be $10 \mathrm{Kg} / \mathrm{cow}$, during worse period of the season .for the design purpose, this study adopted six person per house hold the success of a biogas plant in the rural areas primarily depend on the selection of the plant design size material for construction types of plant and acceptability.

\subsection{Design Considerations}

This work was based on technical, economic and social considerations. The size to use depend on the availability of biodegradable material and amount of gas required, therefore, in this gas, the quality of gas consumed by a household was considered .To design for the volume of the plant, knowledge of the gas required per day, number of dung available, number of family member and hydraulic retention times were the factors of interest. There are many types of digester and of various shapes. But this project adapted the plastic type digester, the bottom line is that the construction should be simple with low demand of material cheap labour, and low in cost land easy to build. The whole plan is constructed to be leak tight to prevent air alteration which can affect the operation of the anaerobic bacteria. The size of the plant is constructed such that it can hold charging material for at least one day the outlet chamber is constructed using an outlet pipe leading the digested slurry from the digester into the chamber where it is removed and utilized as manure. And the gas is led out from the top of digester to a pipe network.

\subsection{Design Calculation}

Following the records accessed from various scholarly performed works on biogas production, the design calculation was carried out thus;

FAO (1996) assumed a daily biogas energy need of 1.5 to $2.0 \mathrm{~m}^{3}$ for a household of six people while Vu et al. (2012) reported that 0.8 to $1.0 \mathrm{~m}^{3}$ of biogas per day would be sufficient to supply the energy needs of a family of 5 - 6 people to cook 3 times daily. The differences in these assessments can be due to variations in the quality of the biogas (that is the $\mathrm{CH} 4$ concentration), which is affected by the composition of the feed entering the digester. It has been reported that daily energy requirement for cooking is estimated to be 0.34 to $0.42 \mathrm{~m}^{3}$ of biogas per person; 1.7 to $2.1 \mathrm{~m}^{3}$ for five people (Singh 
and Sooch, 2004). The digester to be designed and constructed is to serve $100 \%$ of the energy needed for a household of 6 people per day, the capacity of the digester can be calculated thus with daily energy requirement for cooking for an individual is estimated to be 0.34 to $0.42 \mathrm{~m}^{3} /$ day, then, for a household of six people, it becomes 2.04 to $2.52 \mathrm{~m}^{3}$ / day, as estimated by Singh and Sooch, (2004), Therefore the capacity of digester that would be constructed should be able to produce biogas of up to 2.00 to $2.52 \mathrm{~m}^{3} /$ day.

For mixture of animal and kitchen waste, the rate of biogas production is about $0.5 \mathrm{~m}^{3} / \mathrm{kg}$ of volatile solid added as given by (Eze, 2000).

Volatile solid per day $=\frac{\text { Amount of gas generated each day }}{\text { specific gas yield of the substrate }}$

$\frac{2.52}{0.5}=5.40 \mathrm{~kg}$ volatile solid /day

Then with $5.40 \mathrm{~kg}$ volatile solid/day, the volume of digester containing waste could be calculated. But the normal range of volatile solid loading is in the range of $1-4 \mathrm{~kg} \mathrm{vs} / \mathrm{m}^{3} /$ day and the optimal loading rate for animal and kitchen waste is about $2.0 \mathrm{~kg} \mathrm{vs} / \mathrm{m}^{3} /$ day (Eze, 2000; Malaták and Dlabaja, 2011). Then with the volatile solid loading of $2.0 \mathrm{~kg}$ vs $/ \mathrm{m}^{3} /$ day and volatile solid added of $5.4 \mathrm{~kg} /$ day;

Volume of digester containing waste $=\frac{\text { volatile solid per day }(\mathrm{kg} / \mathrm{day})}{\text { volatile solids loading }\left(\frac{\mathrm{kgvs}}{\mathrm{m}^{3}} / \mathrm{day}\right)}$

The volume of digester containing waste $=\frac{5.4 \mathrm{~kg} / \mathrm{day}}{2 \mathrm{kgvs} /\left(\mathrm{m}^{3} / \text { day }\right)}=2.7 \mathrm{~m}^{3}$

From the above equation it follows that, the volume of the digester that could bear the required waste is $2.7 \mathrm{~m}^{3}$.

Volatile solid loading rate is a measure of the biological conversion of the anaerobic digestion system. Feeding the system above its sustainable volatile solid loading rate, results in low biogas yield due to accumulation of inhibitory substances in the digester slurry (fatty acid) (Gray et al., 2008). Under such circumstances, the feeding rate of the system must be reduced.

The amount of biogas generated each day $\left(\mathrm{m}^{3} /\right.$ day) will be calculated on the basis of the daily substrate input (volatile solids content) and specific gas yield of the substrate (Sasse, 1988; Lamand Heegde 2010), such that;

Daily gas production $=$ V.S.C $\times$ S.G.Y

Where, V.S.C = volatile solid content and

S.G.Y= specific gas yield

Volatile solids content $=5.4 \mathrm{~kg} /$ day

Specific gas yield $=0.50 \mathrm{~m}^{3} / \mathrm{kg}$

Daily gas production $=5.4 \mathrm{~kg} /$ day $\times 0.50 \mathrm{~m}^{3} / \mathrm{kg}$

$=2.70 \mathrm{~m}^{3} /$ day $\approx 2.70 \mathrm{~m}^{3} /$ day

The maximum loading capacity of an ideal digester should not exceed $90 \%$ of the digester volume (Eze, 2000). If $2.70 \mathrm{~m}^{3}$ is $75 \%$ of the volume of the digester containing waste required for $2.40 \mathrm{~m}^{3}$ daily biogas production, then the entire volume (that is, $100 \%$ ) is given as $75 \%=2.70 \mathrm{~m}^{3}$

$100 \%=\frac{100 \times 2.70}{75}=3.60 \mathrm{~m}^{3}$

Therefore, the entire digester volume is of $3.60 \mathrm{~m} 3$ with a diameter of $0.56 \mathrm{~m}$ and height of $1.22 \mathrm{~m}$.
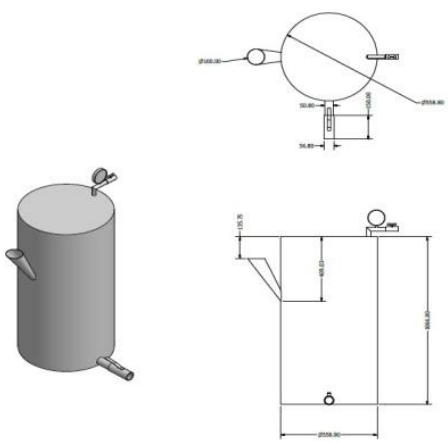

Fig1. Working Diagram of Biogas Digester 


\subsection{Plant Capacity}

For the purpose of this project, the drum type biogas plant was preferred. The digester volume was estimated using equation 4 as given by Okeke and Okeke, (2005).

$V_{d}=\pi r^{2} h_{d}$

where, $V_{d}=$ digester volume,

$h_{d}=$ height of the digester,

$\mathrm{r}=$ radius of the digester.

$h_{d}=1.22 \mathrm{~m}, V_{d}=$ ?, and $\mathrm{r}=0.28 \mathrm{~m}$

$V_{d}=\frac{22}{7} \times 0.28^{2} \times 1.22$

$V_{d}=0.30 \mathrm{~m}^{3}$

$V_{f}=\pi r^{2} h_{f}$

Where

$V_{f}=$ volume of the fluid in the digester,

$\mathrm{r}=$ radius of the digester,

$h_{f}=$ height of slurry in the digester.

Where $h_{f}=0.91 \mathrm{~m}, \mathrm{r}=0.28 \mathrm{~m}$.

$V_{f}=\frac{22}{7} \times 0.28^{2} \times 0.91$

$V_{f}=0.23 \mathrm{~m}^{3}$

Volume of gas space in the digester $=V_{d}-V_{f}$

Volume of gas space $=0.30-0.23$

$=0.07 \mathrm{~m}^{3}$

\subsection{Stress Exerted in the Cylinder}

There are stresses exerted in the biogas cylinder, these are generated from the constituents (gas and the biomas) these stresses are estimated below

Circumferential stress, according to okeke (2005) for a closed vessel

Circumferential stress $=\frac{p d}{2 t}$

where,

$\sigma$-is the yield stress of the plastic chamber.

$\mathrm{p}$-is the safe pressure the chamber can withstand.

$r$-is the radius of the chamber (top and bottom will be considered).

$\mathrm{t}$-is the thickness of the digester.

$\mathrm{d}$-is the diameter of the digester.

Force $=$ Mass $\times$ acceleration due to gravity.

$\mathrm{F}=230 \mathrm{~kg} \times 9.81 \mathrm{~m} / \mathrm{s}^{2}=2256.3 \mathrm{~N}$

$=2.26 \mathrm{KN}$

Area $=2 \times 3.142 \times 0.28 \times 1.22+2 \times 3.142 \times 0.28^{2}$

$=2.64 \mathrm{~m}^{2}$

To determine the pressure that the gas chamber can accommodate using the equation below as given by Okeke, (2005) 
Pressure $=\frac{\text { Force }}{\text { Area }}$

$=\frac{2256.3}{2.64}$

$=854.7 \mathrm{~N} / \mathrm{m}^{2}$

Circumferential stress $\sigma=\frac{854.7 \times 0.56}{2 \times 0.002}$

$=119.66 \mathrm{KN} / \mathrm{m}^{2}$

In order to ensure proper safety and to avoid strain hardening as it will later change the structure to be brittle, a factor of safety of 2 can be taken, hence, Sing and Sooch, (2004) estimated that:

Safe pressure $\mathrm{P}_{\mathrm{s}}=\frac{\text { Yield pressure }}{\text { Factor of safety }}$

$\mathrm{P}_{\mathrm{S}}=\frac{854.7}{2}$

$=427.35 \mathrm{~N} / \mathrm{m}^{2}$

\subsection{Maximum Allowable Stress}

The maximum allowable stress can be calculated from the formula; $\mathrm{S}_{\mathrm{s}}=0.27 \mathrm{Ys}$, as given by Eze, (2000). $Y_{S}$ is the ultimate yield stress for steel.

$\mathrm{S}_{\mathrm{s}}=0.27 \mathrm{Ys}$

$\mathrm{S}_{\mathrm{s}}=0.27 \times 240$

$\mathrm{S}_{\mathrm{s}}=64.8 \mathrm{MPa}$
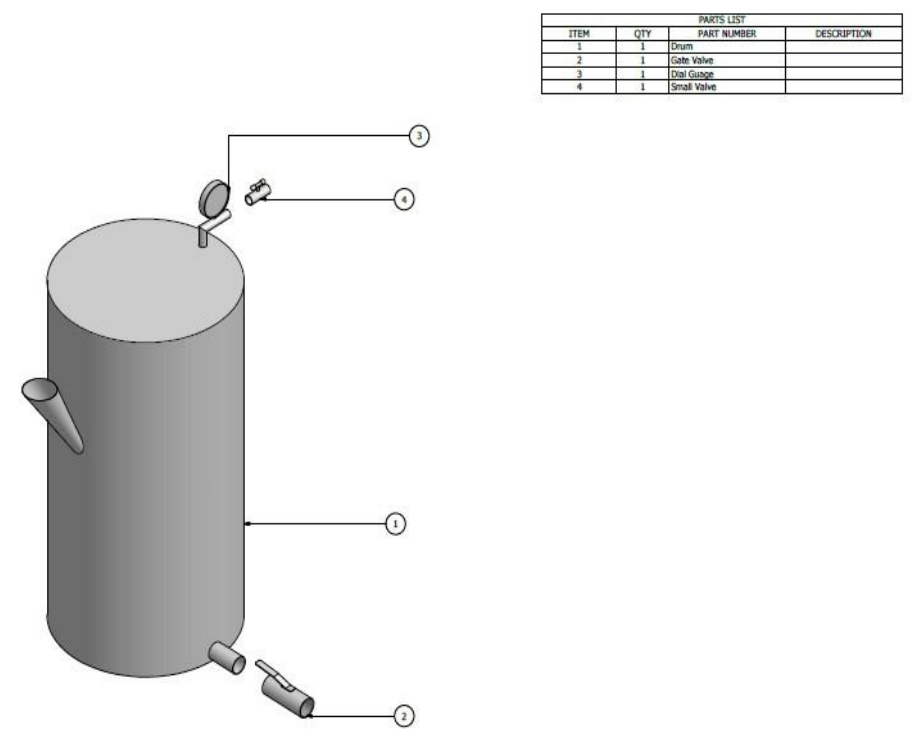

Fig2. Biogas Digester Part list

\begin{tabular}{|c|c|l|}
\hline Item & Quantity & Part name \\
\hline 1 & 1 & Drum \\
\hline 2 & 1 & Gate valve \\
\hline 3 & 1 & Dial guage \\
\hline 4 & 1 & Small valve \\
\hline
\end{tabular}

The electrode is selected and held with the arc welding tong. The electrode is used to strike the metal surface. During the heat generation the arc is struck between the fins and heat generated melts the metals at the welding joint. This process involves cleaning, smoothing and painting of the component to provide an attractive surface required of the product. 


\section{RESULT AND DISCUSSION}

The results of the chemical analysis carried out on the fresh cow dung before and after digestion. The volume of biogas produced was $2.53 \mathrm{~m}^{2}$. The biogas produced was found to compose of $59 \%$ of methane $\left(\mathrm{CH}_{4}\right), 40 \%$ of carbon dioxide $\left(\mathrm{CO}_{2}\right), 0.08 \%$ Hydrogen Sulphide $\left(\mathrm{H}_{2} \mathrm{~S}\right)$ and $0.003 \%$ of water vapour. The average temperature is $38.8 \mathrm{oC}$ which was indicated that the experiment was carried out at mesophilic temperature. The $\mathrm{pH}$ increased gradually until it became 7.0 after digestion which showed the breaking of volatile fatty acids by the methanogenic bacteria to produce neutral slurry.

\subsection{Testing of Biogas}

The biogas produced was tested in a gas burner. A flexible hose which protruded from the outlet of the tube to the bottom mouth of the burner carrying the biogas to the burner as soon as the knob of the burner was released open. The flame of biogas burnt sparsely but strong enough to cook if produced in large volumes. The sparsely burning flame was as a result of carbon dioxide present in the gas. The gas burnt with a bright yellowish flame when the knob of the burner was completely open and also showed bluish flame when the knob was slightly closed to release lesser gas.

\section{CONCLUSION AND RECOMMENDATION}

\subsection{Conclusion}

The biogas production took place after a minimum retention time of four weeks from microbial digestion of cow dung in an anaerobic condition. A biogas digester that is air-proof is a necessary design for this. It can be stated that pretreatment of cow dung for partial digestion before charging fully the digester speeds up the anaerobic digestion process. Biogas production under a mesophilic temperature (between 20 and $45^{\circ} \mathrm{C}$ ) is possible while using an air-tight biogas digester.

\subsection{Recommendation}

It is recommended that biogas digester be cheap, reliable and easy to construct to make it sustainable as such will lead to the exploitation its technological benefit to the rural population. The rural community should be sensitized in harnessing biogas as a means of powering a supplementary electrification program.

\section{ACKNOWLEDGEMENT}

The research team acknowledges the contribution of Tetfund in making the project a reality

\section{REFERENCES}

[1] Abdulkarim N, Katsina CB, Shuaibu N. M., Abubakar M, Isah U (2015). Experimental Investigation on the Effects of Digester Size on Biogas Production from Cow Dung. Am.J. Eng. Res. 4(1):181-186.

[2] Agunwamba, J.C (2001), "Waste Engineering and Management Tool", Immaculate Publication Limited, Enugu, Nigeria.

[3] Amon T, Sangeetha V, and Sivakumar V. (2003). "A review of the biogas programme”. Nepal, China.

[4] Balsam J, Ryan D (2006). Anaerobic digestion of animal wastes: factors to consider. National Sustainable Agriculture Information Service. http://dailyreporter.com/files/2011/01/anaerobic.pdf

[5] Bhumesh SB, Sai VS (2011). Utilization and treatment of dairy effluent through biogas generation A case study. Int. J. Environ. Sci. (1)7:162-172.

[6] Birkmose, C. (1998). "The complete biogas handbook( $3{ }^{\text {rd }}$ edition)",Bourton, UK.

[7] Chukwuma E.C andOrakwe L.C (2014). Anaerobic co-digestion of cattle paunch manure and cow dung for biogas production. ARPN J. Eng. Appl. Sci. 9(6):952-958.

[8] Eze J.I (2000). Design, constuction and performance of batch - operated biogas digester. Ph.D. Dessertation, University of Nigeria Nsukka.

[9] Lofler A,(2000).“Anaerobic digestitionof energy crops without manure addition” Dessel, china

[10] Lopes, W.S., Leite, V.D, and Prasad, S. (2007), "Influence of inoculums on performance of anaerobic reactor for treating municipal solid waste," Bio-resource Technology, No 94; pp 261-266.

[11] Malaták J, Kučera L, andDlabaja T (2011). Biogas composition depending on the type of plant biomass used. Res. Agric. Eng. 57(40):137-143.

[12] Metcalf and Eddy (2016). Wastewater Engineering: Collection, Treatment, Disposal, McGraw-Hill, New York. 
[13] Meynell, P.J. (2013).Methane, Planning a Digester. Prism Press, Dorset, England.

[14] Mukumba P, Makaka G, andShonhiwa C (2015). An assessment of the performance of a biogas digester when insulated with sawdust. Int. J. Energy Power Eng. 4(2):24-31

[15] Okeke, F.N, and Okeke, P.N (2005). Ordinary level physics, evans, Nigeria.

[16] Polprasert.C, Klein DA (1992). Microbiology. 6th Edn., McGraw-Hill Co., New York, London.

[17] Nordberg R, (2002). "Development of Technological regimes for Producing Biogas from Buffalo Dung" Leipzig, Germany.

[18] Raven, S.(2011). "Effect of Biogas and Health" vonyl, india.

[19] Rutz, L. (1996). “Methane, Planning a Digester", Prism Press, Dorset, England.

[20] Singh KJ and Sooch S.S (2004). Comparative study of economics of different models of family size biogas plants for state of Punjab, India. Energy Conver. Manage. (45):1329-1341.

[21] Sasse L (1988). Biogas production using guinea corn and rice husk. J. Microbiol. Biotechnol. Res. (5):5362.

[22] Yadav N, Kumar R, and Rawat LS (2014) Physico-Chemical Properties of before and after anaerobic digestion of Jatropha seed cake and mixed with pure Cow Dung. J. Chem. Eng. Proc. Technol. 5:186-190.

Citation: Ejiko S. O., et.al, (2019)" Development of an House Hold Biogas Digester", International Journal of Modern Studies in Mechanical Engineering, 5(4), pp. 23-32 DOI: http://dx.doi. org/10.20431/2454-9711.0504003

Copyright: (C) 2019 Authors, This is an open-access article distributed under the terms of the Creative Commons Attribution License, which permits unrestricted use, distribution, and reproduction in any medium, provided the original author and source are credited. 